\title{
miR-31 is distinctively overexpressed in primary male extramammary Paget's disease
}

\author{
Hao Guo ${ }^{1, *}$, Rui-Qun Qi ${ }^{1,}{ }^{*}$, Ya-Ni Lv ${ }^{1}$, He-Xiao Wang ${ }^{1}$, Yu-Xiao Hong ${ }^{1}$, Song Zheng ${ }^{1}$, \\ Jiu-Hong $\mathrm{Li}^{1}$, Xing-Hua Gao ${ }^{1}$, Hong-Duo Chen ${ }^{1}$ \\ ${ }^{1}$ Department of Dermatology, No.1 Hospital of China Medical University, Shenyang, China \\ *These authors have contributed equally to this work \\ Correspondence to: Hong-Duo Chen, e-mail: hongduochen@hotmail.com \\ Xing-Hua Gao, e-mail: gaobarry@hotmail.com \\ Jiu-Hong Li, e-mail: Pfkl2011@126.com \\ Keywords: miRNA, miR-31, non-melanoma skin cancer, extramammary Paget's disease, apocrine glands \\ Received: Decemebr 12,2015 Accepted: February 28, $2016 \quad$ Published: March 21, 2016
}

\section{ABSTRACT}

MicroRNAs (miRNAs) are small noncoding RNAs involved in cancer development. Extramammary Paget's disease (EMPD) is a rare cutaneous malignancy and the role of miRNAs in EMPD remains unknown. Here, we used TaqMan miRNA arrays to characterize miRNA expression profile in EMPD and further validated the candidates by single RT-PCR. Total 12 cases EMPD were involved in this study. Using laser capture micro-dissection technique, we collected EMPD tumor cells (ET, $n=12$ ), normal epidermal cells $(N E, n=12$ ) and normal apocrine glands cells (NA, $n=7$ ). MiRNA arrays from two pairs of ET and corresponding NE showed that miR-375, miR-10b, miR-31, miR-31* were differentially expressed. The single real-time PCR (RT-PCR) further confirmed that miR-375, miR-31 and miR-31* were upregulated in EMPD cells than those of the normal epidermis and apocrine glands. Our preliminary study suggested that these miRNAs could be involved in EMPD development and miR-31 may serve as potential biomarkers of EMPD.

\section{INTRODUCTION}

Extramammary Paget's disease (EMPD) is a cutaneous malignancy that always affects apocrine-rich areas such as the vulva, penis, scrotum and perianal area. The pathogenesis of EMPD is still unclear. It shows differentiation to an apocrine gland [1] and the bulk of evidence points to a histogenetic origin of Paget cells from apocrine glands [1-8]. MicroRNAs (miRNAs) are a class of 19-25 nucleotide noncoding RNAs that regulate diverse cellular processes, such as proliferation, differentiation, and cell death. Different miRNAs have been demonstrated to be differentially expressed in tumor tissues and contribute to cancer development [9]. There are currently no any published studies in the role miRNAs in EMPD. Here, we hypothesized that EMPD tumor cells may express a specific miRNA profile, which could contribute to EMPD development.

\section{RESULTS}

To test our hypothesis, fresh frozen tissue samples from 12 EMPD patients were separated into EMPD tumor cells (ET, $n=12)$, normal epidermal cells (NE, $n=12)$ and normal apocrine glands cells (NA, $n=7$ ) precisely via laser capture micro-dissection. By miRNA array analysis, we got specific miRNA expression profiles using two paired samples of ET and NE. Array test was not applicable to NA due to the low quantity in each individual samples. We setup a cut off $\mathrm{Ct}$ value at 35 . In the overall cohort, 406 miRNAs were detected, in which 253 were from pool A and 153 from pool B. Heat-map analysis was performed using the $-\Delta \mathrm{Ct}$ values (Figure 1A) which showed the consistent expression of a majority of miRNAs across different samples. Of 256 miRNAs detected in all samples, we found that four most changed miRNAs, miR-375, miR-10b, miR-31( miR-31-5p) and miR-31* (the complementary miRNA of miR-31, miR-31-3p) were differentially expressed $(|\Delta \Delta \mathrm{Ct}|>4)$ between the NE and ET (Figure 1B).

The differential expression between NE and ET in miRNA array could be influenced by at least two factors: differences between normal and malignant tissues as well as the differences between the cells origin/cell types. To further validate the differentially expressed miRNA 
candidates mentioned above, we preformed TaqMan signal real-time PCR (RT-PCR) on miR-375, miR-10b, miR-31 and $\mathrm{miR}-31^{*}$, using the remaining samples (10 ET, $10 \mathrm{NE}$ and 7 NA). (Figure 1C-1F)

Bonferroni's Multiple Comparison Test was carried out among three groups. Expression levels of miR-31 (Figure 1C) and $\mathrm{miR}-31 *($ Figure $1 \mathrm{D})$ in ET were significantly higher than those from NE and NA $(\mathrm{P}<0.0001)$, while no significant differences between $\mathrm{NE}$ and NA $(\mathrm{P}>0.05)$. The expression level of miR-375 (Figure 1F) showed significant differences among the three groups, ET had the highest level of expression. The expression level of miR-10b (Figure 1E) showed no significant differences among these three groups.
A

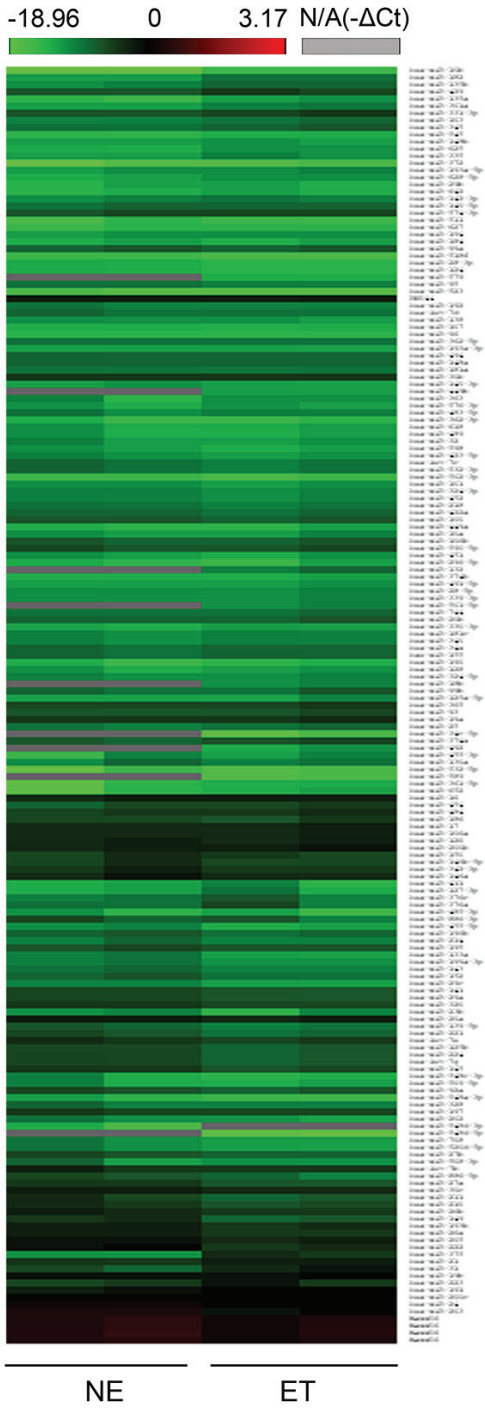

B Differentially expressed miRNAs $(|\Delta \Delta \mathrm{Ct}|>4)$
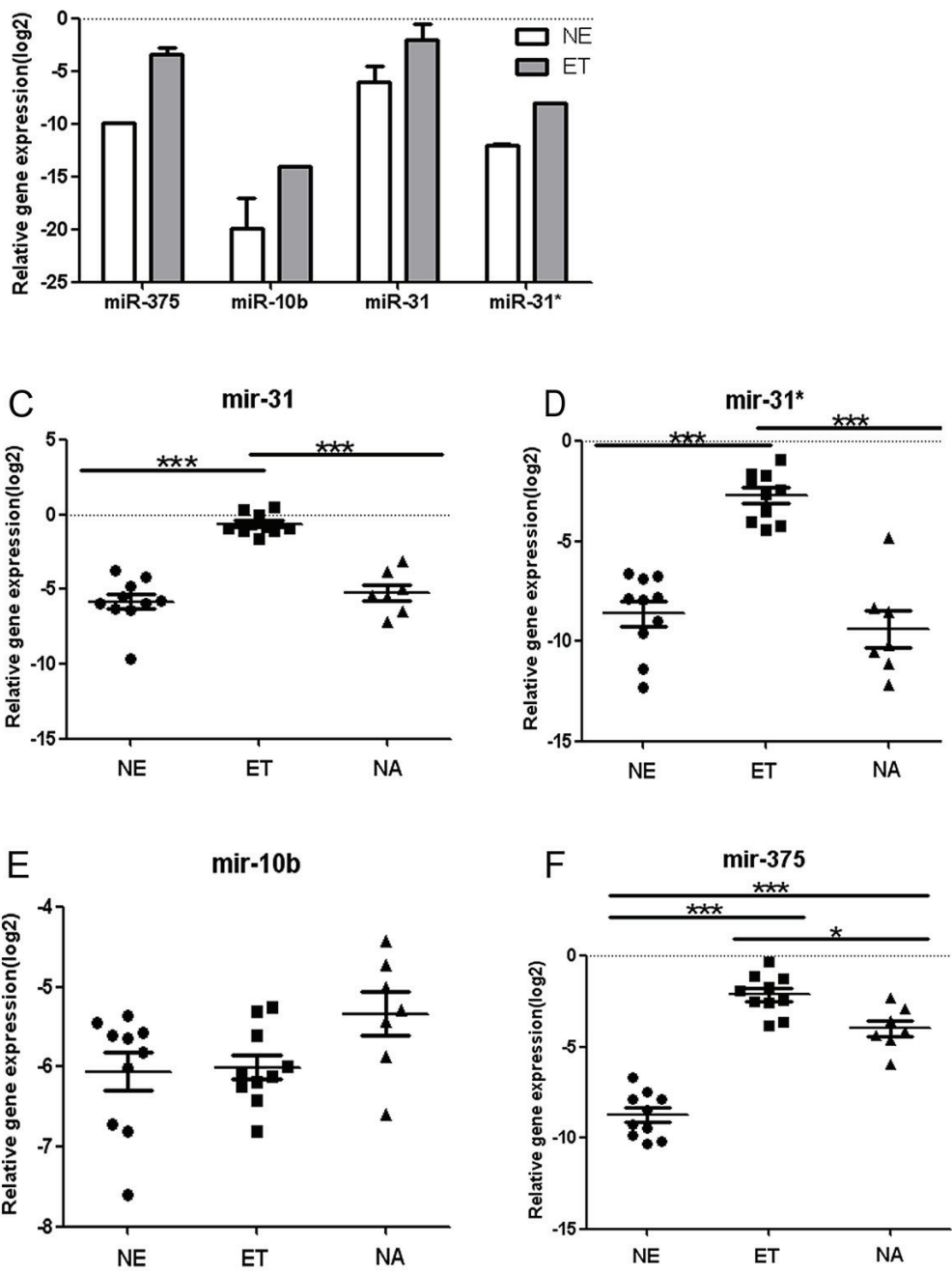

Figure 1: Differentially expressed miRNAs. A. MiRNA expression profiles. MiRNA expressions two pairs of normal epidermal cells (NE) and EMPD tumor cells (ET) from same patients were profiled using TaqMan Human MicroRNA array card A and B (v2.1). The cycle threshold $(\mathrm{Ct})$ values were obtained with SDS 2.3 and RQ manager 1.2 software (Applied Biosystem) and analyzed with RealTime StatMiner ${ }^{\circledR} 4.2$ software (Integromics, Inc.). The $-\Delta \mathrm{Ct}\left[-\left(\mathrm{Ct}_{-}-\mathrm{Ct}_{\mathrm{RNU} 48}\right)\right]$ was calculated and heat map analysis was performed with hierarchical clustering. A green-red color scale (-18.96 to 3.17) depicts normalized miRNAs expression level based on internal control (RNU48), and grey represents undetected. B. Different expression of miRNAsin ET and NE, based on the array analysis. The expression levels (- $\Delta \mathrm{Ct})$ of miR-375, miR-10b, miR-31 and miR-31* in ET were much higher than that in NE. $|\Delta \Delta \mathrm{Ct}| \geq 4, \Delta \Delta \mathrm{Ct}=\Delta \mathrm{Ct} \mathrm{ET}_{\mathrm{ET}}-\Delta \mathrm{Ct} \mathrm{NE}_{\mathrm{NE}}$. C-F. The relative gene expression level $(-\Delta \mathrm{Ct})$ of miR-31(c), miR-31*(d), miR-10b(e) and miR-375(f) in ET(n=10), NE(n=10) and normal apocrine glands cells (NA, $\mathrm{n}=7) .(*: \mathrm{P}<0.05, * * *: \mathrm{P}<0.0001)$. 


\section{DISCUSSION}

MiR-31 is expressed widely in different cell types [10-13] and has been extensively studied in different cancers. Its expression has been found to be down-regulated in human carcinomas of the prostate [14], ovary [15], and stomach [16]. Paradoxically, up-regulation of miR-31 has been shown in human cervical [17], colorectal [18, 19], liver [20] and head-and-neck squamous cell carcinomas [21, 22]. Liu et al [21] showed that miR-31 has the capacity to promote primary tumor growth in head-and- neck squamous cell carcinoma. In relation to its up-regulated expression in EMPD, we suspect that miR-31 may correlate with the development of EMPD, considering that the possible source cells from apocrine glands had moderate expression. According to the data of Mirbase, miR-31 has 176 validated target genes. Among them only SP1 (specific protein1) and AR (androgen receptor) have been studied in EMPD. While both SP1 and AR were higher expressed in EMPD through immunohistochemical stain [23-25], indicating they were unlikely to be related with the overexpression of miR-31 directly. MiR-31* is the complementary miRNA of miR-31. MiR-31*expression was consistent with miR-31 (Figure 1C, 1D), indicating a generalized deregulation in the precursor transcript from which these mature miRNAs are derived.

MiR-375 has been found to be dysregulated in numerous types of malignancy acting as either tumor suppressors or oncogenes [26-33]. We suspect the overexpression of mir-375 may correlate with the development of EMPD. In our observation, the inconsistency of miR-10b between array and single RT-PCR might be induced by the limited number of samples in the array.

This is the first report to indicate that miR-31, miR-31* and miR-375 were overexpressed in EMPD and miR-31 could be served as a potential biomarkers of EMPD. However, further studies using a large cohort are needed to identify their targets and related singling pathways involve in EMPD development.

\section{PATIENTS AND METHODS}

\section{Patients}

We collected archived 12 male patients (Supplementary Table S1, available online) with clinically and histologically confirmed EMPD aged from 56 to 79 year-old. These patients all came from Northeast China, and other malignancies had been ruled out via comprehensive examinations (including chest $\mathrm{CT}$, abdominal \& urinary system B ultrasonic and enteroscope) prior to surgery. To minimize the heterogeneity among our cancer cases, samples from perianal area were excluded in this study.

\section{Laser capture micro-dissection}

Twelve fresh frozen EMPD tumor tissues underwent sectioning and staining. By laser capture micro-dissection (MMI cellcut), EMPD tumor cells (ET), normal epidermal cells (NE) and normal apocrine gland cells (NA) were precisely isolated, respectively (Supplementary Figure S1, available online)

\section{RNA isolation}

All the collected tissue of these three groups underwent lysis and extraction of total RNA including miRNA by Qiagen miRNeasy Micro Kit with the protocol provided by Qiagen.

\section{TaqMan low-density array miRNA qRT-PCR}

Due to limited RNA could be obtained using microdissection technique, a preamplification step was added per manufacture's protocol when miRNA array was performed in two paired samples of ET and NE from same patients for gross screening. The RNA was reverse transcribed using the TaqMan MiRNA Reverse Transcription Kit and the TaqMan miRNA Multiplex RT Assays, Human pool A, B (V2.1, V3.0, respectively). The expression was profiled with TaqMan Human microRNA arrays (V2.1 for pool A and V3.0 for pool B), using the manufacturer's recommended protocol (Applied Biosystems, Foster City, CA, USA).

\section{Single real-time PCR (RT-PCR)}

Upon obtaining significantly differentially expressed miRNAs, RT-PCR was performed on specific miRNAs among the three groups of cells using the remaining samples (10 ET, $10 \mathrm{NE}$ as well as $7 \mathrm{NA}$ ). Due to their scarcity, NA from EMPD patients could not be found in every samples.

\section{Data analysis}

For miRNAs that were observed in all samples, cycle threshold $(\mathrm{Ct})$ values were obtained with SDS 2.3 and RQ manager 1.2 software (Applied Biosystem), and $\Delta \mathrm{Ct}$ values were used in the statistical analysis. Differential expression of miRNAs were calculated with StatMiner ${ }^{\circledR} 4.2$ (Integromics ${ }^{\circledR}$ Inc., Philadelphia, PA). $-\Delta \mathrm{Ct}\left[-\left(\mathrm{Ct}-\mathrm{Ct}_{\mathrm{RNU} 48}\right)\right]$ was calculated and heat map analysis was performed with hierarchical clustering. Histograph and scattergraph was performed by GraphPad Prism.

Detailed methods and data analysis are shown in Supplementary Methods. 


\section{ACKNOWLEDGMENTS}

This study was supported by Program for Innovative Research teams of Liaoning Educational Bureau (LT2011011).

\section{CONFLICTS OF INTEREST}

The authors declared no conflict of interests.

\section{REFERENCES}

1. Fujimoto A, Takata M, Hatta N, Takehara K. Expression of structurally unaltered androgen receptor in extramammary Paget's disease. Lab Invest. 2000; 80:1465-1471.

2. Wagner G, Sachse MM. Extramammary Paget disease clinical appearance, pathogenesis, management. J Dtsch Dermatol Ges. 2011; 9:448-454.

3. Merot Y, Mazoujian G, Pinkus G, Momtaz TK, Murphy GF. Extramammary Paget's disease of the perianal and perineal regions. Evidence of apocrine derivation. Arch Dermatol. 1985; 121:750-752.

4. Mazoujian G, Pinkus GS, Haagensen DE. Extramammary Paget's disease--evidence for an apocrine origin. An immunoperoxidase study of gross cystic disease fluid protein-15, carcinoembryonic antigen, and keratin proteins. Am J Surg Pathol. 1984; 8:43-50.

5. Hanna W, Alowami S, Malik A. The role of HER-2/neu oncogene and vimentin filaments in the production of the Paget's phenotype. Breast J. 2003; 9:485-490.

6. Giger O, Caduff R, O'Meara A, Diener PA, Knuth A, Jager D, Moch H, Varga Z. Frequent expression of the breast differentiation antigen NY-BR-1 in mammary and extramammary Paget's disease. Pathol Int. 2010; 60:726-734.

7. Imam A, Yoshida SO, Taylor CR. Distinguishing tumour cells of mammary from extramammary Paget's disease using antibodies to two different glycoproteins from human milk-fat-globule membrane. Br J Cancer. 1988; 58:373-378.

8. Tamaki K, Hino H, Ohara K, Furue M. Lectin-binding sites in Paget's disease. Br J Dermatol. 1985; 113:17-24.

9. Duttagupta R, Jiang R, Gollub J, Getts RC, Jones KW. Impact of cellular miRNAs on circulating miRNA biomarker signatures. PLoS One. 2011; 6:e20769.

10. Yang S, Xie N, Cui H, Banerjee S, Abraham E, Thannickal VJ, Liu G. miR-31 is a negative regulator of fibrogenesis and pulmonary fibrosis. FASEB J. 2012; 26:3790-3799.

11. Peng H, Hamanaka RB, Katsnelson J, Hao LL, Yang W, Chandel NS, Lavker RM. MicroRNA-31 targets FIH-1 to positively regulate corneal epithelial glycogen metabolism. FASEB J. 2012; 26:3140-3147.

12. Pedrioli DM, Karpanen T, Dabouras V, Jurisic G, van de Hoek G, Shin JW, Marino D, Kalin RE, Leidel S, Cinelli P, Schulte-Merker S, Brandli AW, Detmar M. miR-31 functions as a negative regulator of lymphatic vascular lineage-specific differentiation in vitro and vascular development in vivo. Mol Cell Biol. 2010; 30:3620-3634.

13. Suarez Y, Wang C, Manes TD, Pober JS. Cutting edge: TNF-induced microRNAs regulate TNF-induced expression of E-selectin and intercellular adhesion molecule-1 on human endothelial cells: feedback control of inflammation. J Immunol. 2010; 184:21-25.

14. Schaefer A, Jung M, Mollenkopf HJ, Wagner I, Stephan C, Jentzmik F, Miller K, Lein M, Kristiansen G, Jung K. Diagnostic and prognostic implications of microRNA profiling in prostate carcinoma. Int J Cancer. 2010; 126:1166-1176.

15. Creighton CJ, Fountain MD, Yu Z, Nagaraja AK, Zhu H, Khan M, Olokpa E, Zariff A, Gunaratne PH, Matzuk MM, Anderson ML. Molecular profiling uncovers a p53-associated role for microRNA-31 in inhibiting the proliferation of serous ovarian carcinomas and other cancers. Cancer Res. 2010; 70:1906-1915.

16. Guo J, Miao Y, Xiao B, Huan R, Jiang Z, Meng D, Wang $Y$. Differential expression of microRNA species in human gastric cancer versus non-tumorous tissues. J Gastroenterol Hepatol. 2009; 24:652-657.

17. Zheng $\mathrm{W}$, Liu Z, Zhang W, Hu X. miR-31 functions as an oncogene in cervical cancer. Arch Gynecol Obstet. 2015; 292:1083-1089.

18. Bandres E, Cubedo E, Agirre X, Malumbres R, Zarate R, Ramirez N, Abajo A, Navarro A, Moreno I, Monzo M, Garcia-Foncillas J. Identification by Real-time PCR of 13 mature microRNAs differentially expressed in colorectal cancer and non-tumoral tissues. Mol Cancer. 2006; 5:29.

19. Motoyama K, Inoue H, Takatsuno Y, Tanaka F, Mimori K, Uetake H, Sugihara K, Mori M. Over- and under-expressed microRNAs in human colorectal cancer. Int J Oncol. 2009; 34:1069-1075.

20. Wong QW, Lung RW, Law PT, Lai PB, Chan KY, To KF, Wong N. MicroRNA-223 is commonly repressed in hepatocellular carcinoma and potentiates expression of Stathmin1. Gastroenterology. 2008; 135:257-269.

21. Liu CJ, Tsai MM, Hung PS, Kao SY, Liu TY, Wu KJ, Chiou SH, Lin SC, Chang KW. miR-31 ablates expression of the HIF regulatory factor FIH to activate the HIF pathway in head and neck carcinoma. Cancer Res. 2010; 70:1635-1644.

22. Liu X, Chen Z, Yu J, Xia J, Zhou X. MicroRNA profiling and head and neck cancer. Comp Funct Genomics. 2009; 837514.

23. Lee MW, Jee KJ, Gong GY, Choi JH, Moon KC, Koh JK. Comparative genomic hybridization in extramammary Paget's disease. Br J Dermatol. 2005; 153:290-294.

24. Liegl B, Horn LC, Moinfar F. Androgen receptors are frequently expressed in mammary and extramammary Paget's disease. Mod Pathol. 2005; 18:1283-1288.

25. Chen SY, Takeuchi S, Moroi Y, Hayashida S, Kido M, Uchi H, Takahara M, Uenotsuchi T, Tu YT, Urabe K, Furue 
M. Concordant over-expression of transcription factor Sp1 and vascular endothelial growth factor in extramammary Paget's disease. Int J Dermatol. 2008; 47:562-566.

26. Mathe EA, Nguyen GH, Bowman ED, Zhao Y, Budhu A, Schetter AJ, Braun R, Reimers M, Kumamoto K, Hughes D, Altorki NK, Casson AG, Liu CG, et al. MicroRNA expression in squamous cell carcinoma and adenocarcinoma of the esophagus associations with survival. Clin Cancer Res. 2009; 15:6192-6200.

27. Saito Y, Saito H. Role of CTCF in the regulation of microRNA expression. Front Genet. 2012; 3:186.

28. Yabushita S, Fukamachi K, Tanaka H, Sumida K, Deguchi Y, Sukata T, Kawamura S, Uwagawa S, Suzui M, Tsuda H. Circulating microRNAs in serum of human K-ras oncogene transgenic rats with pancreatic ductal adenocarcinomas. Pancreas. 2012; 41:1013-1018.

29. Yu L, Todd NW, Xing L, Xie Y, Zhang H, Liu Z, Fang H, Zhang J, Katz RL, Jiang F. Early detection of lung adenocarcinoma in sputum by a panel of microRNA markers. Int J Cancer. 2010; 127:2870-2878.
30. Kinoshita T, Hanazawa T, Nohata N, Okamoto Y, Seki N. The functional significance of microRNA-375 in human squamous cell carcinoma: aberrant expression and effects on cancer pathways. J Hum Genet. 2012; 57:556-563.

31. Harris T, Jimenez L, Kawachi N, Fan JB, Chen J, Belbin T, Ramnauth A, Loudig O, Keller CE, Smith R, Prystowsky MB, Schlecht NF, Segall JE, et al. Low-level expression of miR-375 correlates with poor outcome and metastasis while altering the invasive properties of head and neck squamous cell carcinomas. Am J Pathol. 2012; 180:917-928.

32. Wang F, Li Y, Zhou J, Xu J, Peng C, Ye F, Shen Y, Lu W, Wan X, Xie X. miR-375 is down-regulated in squamous cervical cancer and inhibits cell migration and invasion via targeting transcription factor SP1. Am J Pathol. 2011; 179:2580-2588.

33. Mao Q, Quan T, Luo B, Guo X, Liu L, Zheng Q. MiR-375 targets KLF4 and impacts the proliferation of colorectal carcinoma. Tumour Biol. 2015. 